\title{
Образовна структура запослених у јавним библиотекама Србије
}

\author{
Анђела Стошић \\ Универзитет у Београду \\ Филолошки факултет - Катедра за библиотекарство и информатику, Београд \\ andjela.stosic@fil.bg.ac.rs \\ Ана Ђорђевић \\ Универзитет у Београду \\ Хемијски факултет - Библиотека, Београд \\ anadj@chem.bg.ac.rs
}

\begin{abstract}
Сажетак
У раду је приказана структура кадра у јавним библиотекама Републике Србије према степену и области образовања. Издвојени су подаци за 2013. и 2018. годину како би се установио ефекат забране запошљавања у јавном сектору која је донета крајем 2013. Евидентно је да се број запослених са средњом и вишом стручном спремом смањио, док је број високообразованих повећан.

Како се у постојећем закону и националним стандардима који се односе на библиотечко-информациону делатност не издваја образовни профил дипломираног библиотекара као приоритетан приликом запошљавања, циљ је утврдити из којих струка долазе високообразовани запослени у јавним библиотекама. Као посебна категорија издвојени су упосленици са дипломом из области библиотекарства и информатике, да би се сагледало који проценат заузимају међу универзитетски образованим кадром.

Чињеница да је број корисника библиотека испод утврђеног стандарда, указује да је потребно променити нешто у начину рада јавних библиотека. За почетак би било добро преиспитати тренутно стање у Србији и проучити прописе земаља које су ово питање решиле на адекватнији начин те на основу тога експлицитније прописати који би образовни профили, у коликој мери, требало да буду заступљени у јавним библиотекама.
\end{abstract}

Кључне речи: јавне библиотеке, структура запослених, библиотекари, образовање, катедре за библиотекарство и информатику, Република Србија

\section{Увод}

Више од половине свих запослених у библиотекама у Републици Србији чини особље јавних библиотека и њихових огранака. ${ }^{1}$ Како су јавне библиотеке отворене и намењене грађанима свих узраста, нивоа образовања и интересовања, тако су и њихови фондови богати разноврсном грађом, а службеници различитог образовног профила. Циљ рада је да детаљније прикаже структуру стручног кадра у јавним библиотекама према степену и области образовања и укаже на потребу да се експлицитније пропише који би образовни профили у коликој мери требало да буду заступљени у библиотекама овог типа.

Рад се највећим делом заснива на подацима које прикупља Одељење за истраживање и развој библиотечко-информационог система - Матично одељење Народне библиотека Србије. ${ }^{2}$ Статистички подаци о службеницима који раде на библиотечко-информационим пословима у јавним библиотекама и њиховим огранцима, узети за 2013. и 2018. годину,

\footnotetext{
1 Од укупно 3688 запослених у библиотекама Србије са пунима радним временом, 1911 ради у јавним библиотекама. Видети: Републички завод за статистику и Завод за проучавање културног развитка, Кулшшура 2017 (Београд: Републички завод за статистику, 2018), 48, преузето 25. 8. 2019, http://publikacije.stat.gov.rs/G2018/Pdf/G20186003.pdf.

2 Податке и помоћ у њиховом тумачењу љубазно је пружила Марина Митрић, дипломирани библиотекар-саветник, на чему јој се ауторке искрено захваљују.
} 
показују степен њихове стручне спреме и, у оквиру њега, назив завршене школе/факултета и смер, односно студијски профил. Текст се, дакле, не бави стручним звањима која они имају у библиотеци. Радом нису обухваћени они који су ангажовани на помоћним и другим пословима ван библиотечко-информационе струке. Због неажурности појединих библиотека приликом достављања података о својим радницима, изнесене бројке не могу бити сасвим прецизне.

У првом одељку анализирана је структура запослених на библиотечко-информационим пословима у јавним библиотекама Србије према степену образовања у 2013. и 2018. години. Други део рада бави се образовним профилима упосленика са високом стручном спремом.

\section{Структура запослених према степену образовања}

Према подацима за 2013. годину, у 509 јавних библиотека и огранака ${ }^{3}$ у Србији, радило је 1912 запослених на стручним пословима ${ }^{4}$ са пуним радним временом. Њихова структура према нивоу образовања дата је на графичком приказу бр 1.

На другом графичком приказу представљена је структура у 2018. години, када је у 519 јавних библиотека и њихових огранака ${ }^{5}$ радило 1875 запослених. Највећи део чине они са високом стручном спремом, нешто мањи број је са завршеном средњом школом, док мање од десетине службеника има вишу стручну спрему.

Број стручних упосленика у јавним библиотекама у Републици Србији за пет година опао је за 37, односно 1,9\% у односу на 2013. Међутим, како се број библиотека евидентно повећао, запослених је мање у односу на број установа у којима раде. Уколико се узме просечан број запослених по јавној библиотеци, који за 2013. износи $3,75,{ }^{6}$ док је у 2018 . он $3,61,{ }^{7}$ може се закључити да је стручних радника мање за $3,73 \%$ у року од пет година.

Смањење броја запослених није необично, с обзиром на то да је крајем 2013. године уведена забрана запошљавања у јавном сектору, којој је управо то и био циљ. Приметно је, такође, да је ова ситуација највише погодила раднике са средњом и вишом стручном спремом. Наиме, на графичком приказу бр. 1 може се видети да је у 2013. доминирао кадар са средњошколским образовањем, који је чинио $44,24 \%$ ангажованих на библиотечко-информационим пословима, док у 2018. они чине $41,65 \%$, јер се њихов број смањио за $83 .{ }^{8}$ Нижи је, такође, број упосленика са вишом школском спремом - у 2013. су чинили 12,86\%, у 2018. $-9,70 \% .{ }^{9}$ Насупрот томе, повећала се заступљеност високообразованог кадра. У 2018. години,

\footnotetext{
3159 главних јавних/општинских/градских библиотека и 350 огранака и одељења на издвојеним локацијама.

${ }^{4}$ Према актуелном закону, стручне библиотечке послове обављају књижничари, виши књижничари, библиотекари и дипломирани библиотекари. Видети: „Закон о библиотечко-информационој делатности“, Службени іласник Рейублике Србије бр. 52 (2011), преузето 10. 8. 2019, http://www.kultura.gov.rs/docs/dokumenti/propisi-iz-oblasti-kulture/-zakon-o-bibliotecko-informacionojdelatnosti.doc.

5 у 2018. години било је 160 главних јавних/општинских/градских библиотека и 359 огранака и одељења на издвојеним локацијама. Једна јавна библиотека више у односу на 2013. годину не значи да се отворила потпуно нова установа. Ради се о случају Библиотеке „Нсидора Секулић“ у општини Савски венац, која је, судском пресудом 2011. године, остала без свог простора у Архиву Југославије и била пресељена у један од огранака. Године 2018. Библиотека је добила нове просторије и повратила свој некадашњи статус.

Запажа се разлика и у броју огранака између 2013. и 2018. Према речима Марине Митрић, то је последица различитих ситуација - отварање потпуно нових огранака, затварање старих, који неколико година нису радили, па поновно отварање, али на другој физичкој локацији/у другом насељу, затварање неког огранка ради реновирања или неусловног простора, па сређивање простора и поновно отварање на истој локацији, али после неколико година, трајно затварање органка. Марина Митрић, E-mail порука ауторки Ани Ђорђевић, 10. 10. 2019.

6 1912: 509.

7 1875: 519

8 Готово трећина стручних радника са свршеном средњом школом образовала се у гимназијама. Још увек постоје и они који су знање стицали у Средњој библиотекарској школи (1948-1979) - 2013. године било их је 66, док се у 2018. години број свео на 34.

9 Око 30\% ових радника има завршену Вишу педагошку школу.
} 
Стошић А. и др. „Образовна структура запослених у јавним библиотекама Србије“, 2-9

\section{ЗАПОСЛЕНИ У ЈАВНИМ БИБЛИОТЕКАМА СРБИЈЕ ПРЕМА СТЕПЕНУ ОБРАЗОВАҢА У (2013)}

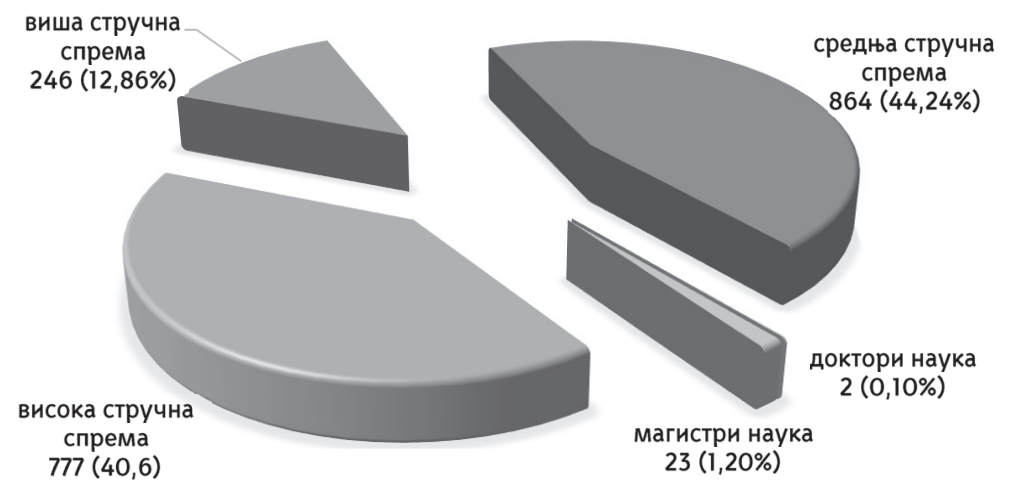

Графички приказ бр. 1

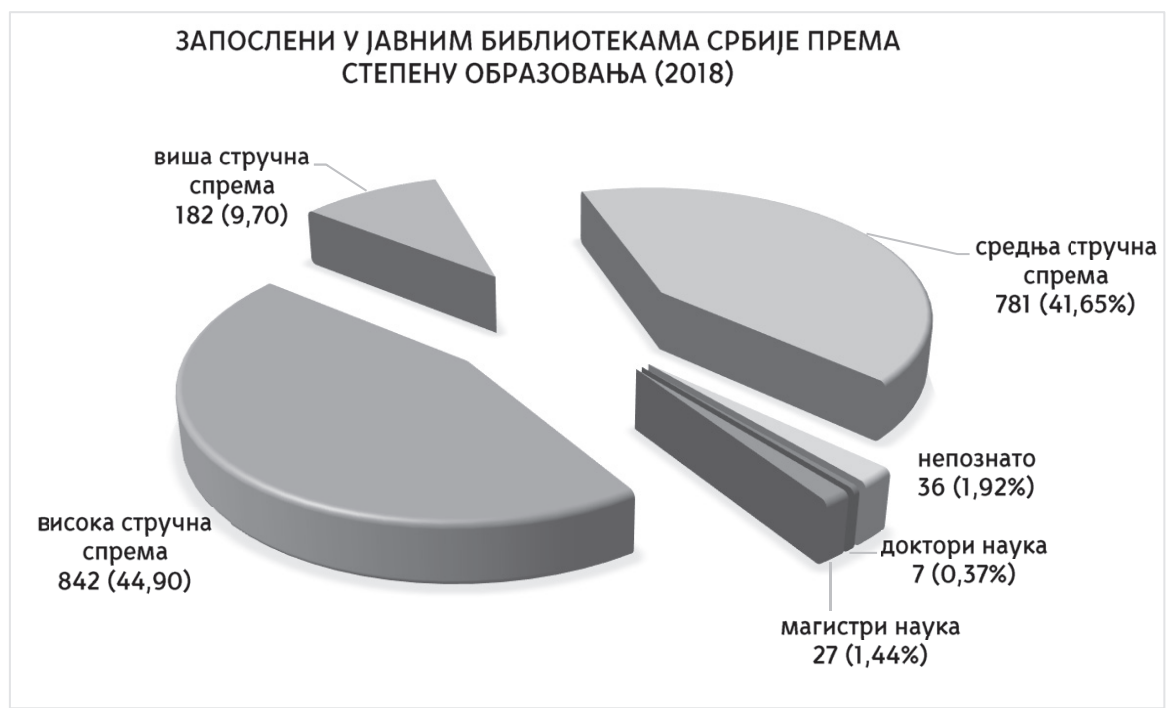

Графички приказ бр. 2

универзитетски образовано особље заузимало је $46,81 \%,{ }^{10}$ док је пет година раније било заступљено са 41,9 процената. Да већ годинама постоји тренд промене структуре у корист високообразованог кадра, говори и податак везан за матичне библиотеке, где је, пре двадесетак година, 48,37\% службеника имало завршену средњу школу, 17,81\% вишу, док је са високом стручном спремом било тек $33,82 \%$ стручног особља. ${ }^{11}$

Овакве промене су у складу са општим токовима у друштву. Наиме, у данашње време, млади чешће одлучују да студирају те је и већа понуда високообразованог кадра. Више образовање у

\footnotetext{
10 Доктора наука, магистара и осталих високообразованих

11 Гордана Стокић, „Запослени у библиотекама о себи или има ли места осећању инфериорности?“, Зајеgнии,а библиошека: инфор-

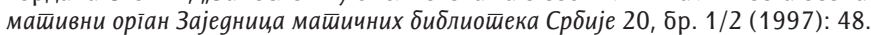


некадашњем смислу не постоји, већ су то високе школе са чијим се дипломама у библиотеци може имати звање библиотекара. Они који ипак не заврше факултет или високу школу углавном се окрећу траженијим или уноснијим занимањима, пре свега у области информационих технологија. Добар број људи, како са факултетском дипломом, тако и они без ње, одлази ${ }^{12}$ или размишља о одласку у иностранство. ${ }^{13}$

\section{Структура високообразованог кадра}

Универзитетски образован кадар данас чини већинску групу међу запосленима у јавним библиотекама и свакако би требало да представља носиоца библиотечко-информационе делатности у Србији. Како би се дочарао диверзитет високообразованог стручног кадра у 2013. и 2018. години, сви упосленици, за које постоји податак о завршеном факултету, подељени су у 16 категорија, седамнаестој припадају они за које нису уписани подаци о установи на којој су дипломирали или образовном профилу. ${ }^{14}$

На графичком приказу бр. 3 може се видети да од укупно 802 високообразована радника у 2013. години, за 97 њих нема податка о завршеном факултету. ${ }^{15}$ Вероватно очекивано, најбројнија група у оквиру ове структуре јесу филолози. Обухватали су $37,45 \%{ }^{16}$ места на стручним библиотечким пословима. Професора српског језика и књижевности и југословенске књижевности било је 19,43\%, док је професора страних језика, компаратиста књижевности и лингвиста било $18,01 \%$. Запослени који су завршили студије друштвених наука на неком од филозофских факултета обухватали су 20,28\%. Међу њима је највише историчара, затим филозофа, социолога, педагога, историчара уметности, етнолога, андрагога.

Особље са дипломом из библиотечко-информационе делатности чинило је 9,93\% универзитетски образованог кадра. Запослени који су завршили учитељски факултет били су заступљени са 8,65\%.

Од 876 запослених са високим образовањем у 2018. години, укупно 267 има диплому из области језика и књижевности. Ту спадају професори српског језика и књижевности, или југословенске књижевности којих има 138 или 17,81\%, и професори страних језика и књижевности, компаратисти и лингвисти - 129 или 16,65\%. ${ }^{.7}$ Следећа категорија по заступљености припада особљу са дипломом из друштвених наука на филозофским факултетима (19,35\%).

Као посебне категорије, у графичком приказу бр. 3 издвојени су библиотекари образовани на Катедри за библиотекарство и информатику Филолошког факултета (70), затим они који су диплому стекли на Педагошком факултету (4) и они који су дипломирали у областима компаративна књижевност са библиотекарством и општа књижевност са библиотекарством (7). Одавде се може видети да у јавним библиотекама ради 81 библиотекар са дипломом из библиотечко-информационих наука, тј. да они чине 10,45\% високоообразованог стручног кадра.

\footnotetext{
12 Портал Блии, наводи податке OECID-а који показују да годишње из Србије одлази око 49.000 људи. Bидети: N. Govoruša „Porazno zvanično istraživanje: Srbija zbog mladih koji odlaze gubi i do dve milijarde evra godišnje“, Blic, preuzeto 1. 10. 2019, https:// www.blic.rs/biznis/vesti/porazno-zvanicno-istrazivanje-srbija-zbog-mladih-koji-odlaze-gubi-i-do-dve-milijarde/xdggs9e.

13 Чак 36\% младих размишља да оде из Србије. Видети: Katarina Stevanović, „Zašto mladi iz Srbije odlaze u inostranstvo i zašto se ponekad vraćaju“" BBC News na srpskom, preuzeto 1. 10. 2019, https://www.bbc.com/serbian/lat/svet-46062846

14 Подела се није могла извршити само према називу факултета, јер се исте науке могу изучавати на различитим високообразовним институцијама те није било пожељно, на пример, раздвајати професоре језика и књижевности који су дипломирали на Филолошком факултету од оних на Филозофском. Такође, неки сродни факултети спојени су у једну категорију, како структура не би била превише детаљна. Факултети који су имали мање од 10 представника сврстани су у категорију „остало“.

15 Како се може приметити, и за 2013. и за 2018. недостају подаци за више од 10\% запослених са високом стручном спремом. С обзиром на то да је матична служба Народне библиотеке Србије доставила само податке које јавне библиотеке њој шаљу, одговорност за овакву ситуацију приписује се матичним библиотекама, или онима које нису испуниле своју обавезу према матичној библиотеци.

16 Од 705 запослених за које постоје подаци о завршеном факултету.

17 Проценат у односу на 775 високообразованих
} 


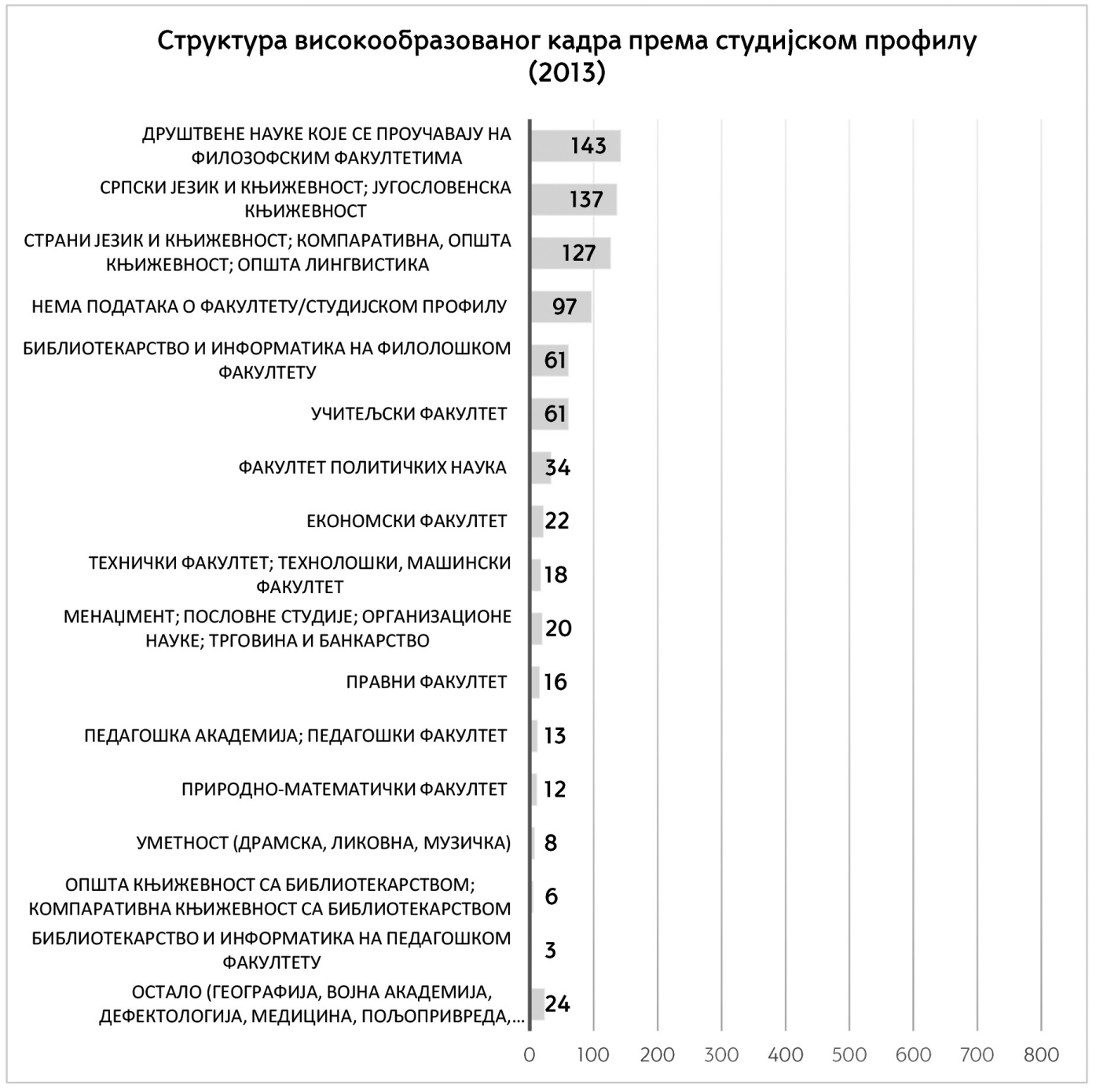

\section{Графички приказ бр. 3}

Још једну од бројнијих група чине запослени са дипломом учитељског факултета, којих има 72 или 9,29\%. Остале категорије имају далеко мање представника, међутим, није занемарљив ни проценат запослених са Факултетом политичких наука и из области менаџмента $(4,39 \%)$. Постоји и одређени број економиста, правника, па чак и понеко из сфере природних наука, уметности, машинства, пољопривреде и других.

Подаци указују да је структура запослених за ових пет година минимално промењена. Проценат филолога се смањио са 37,45\% на 34,46\%. Промена иде у корист менаџера (са 2,84\% на 4,39\%), економиста (са 3,12\% на 4,13\%), библиотекара са катедара за библиотечко-информационе науке (са 9,93\% на 10,45\%), учитеља (8,65\% на 9,29\%).

Закон о библиотечко-информационој делатности тренутно не прави никакву разлику између дипломираних стручњака из области библиотекарства и оних из ма које друге области, осим што први имају привилегију да су поменути у првом ставу, док су остали смештени у други став члана 46, који прописује ко може обављати послове дипломираног библиотекара. За све важи исто правило - поменуто звање добијају тек када положе стручни испит. Национални стандарди за обављање библиотечко-информационе делатности врло прецизно могу одредити колико је пута годишње потребно темељно очистити просторије јавне библиотеке - четири 


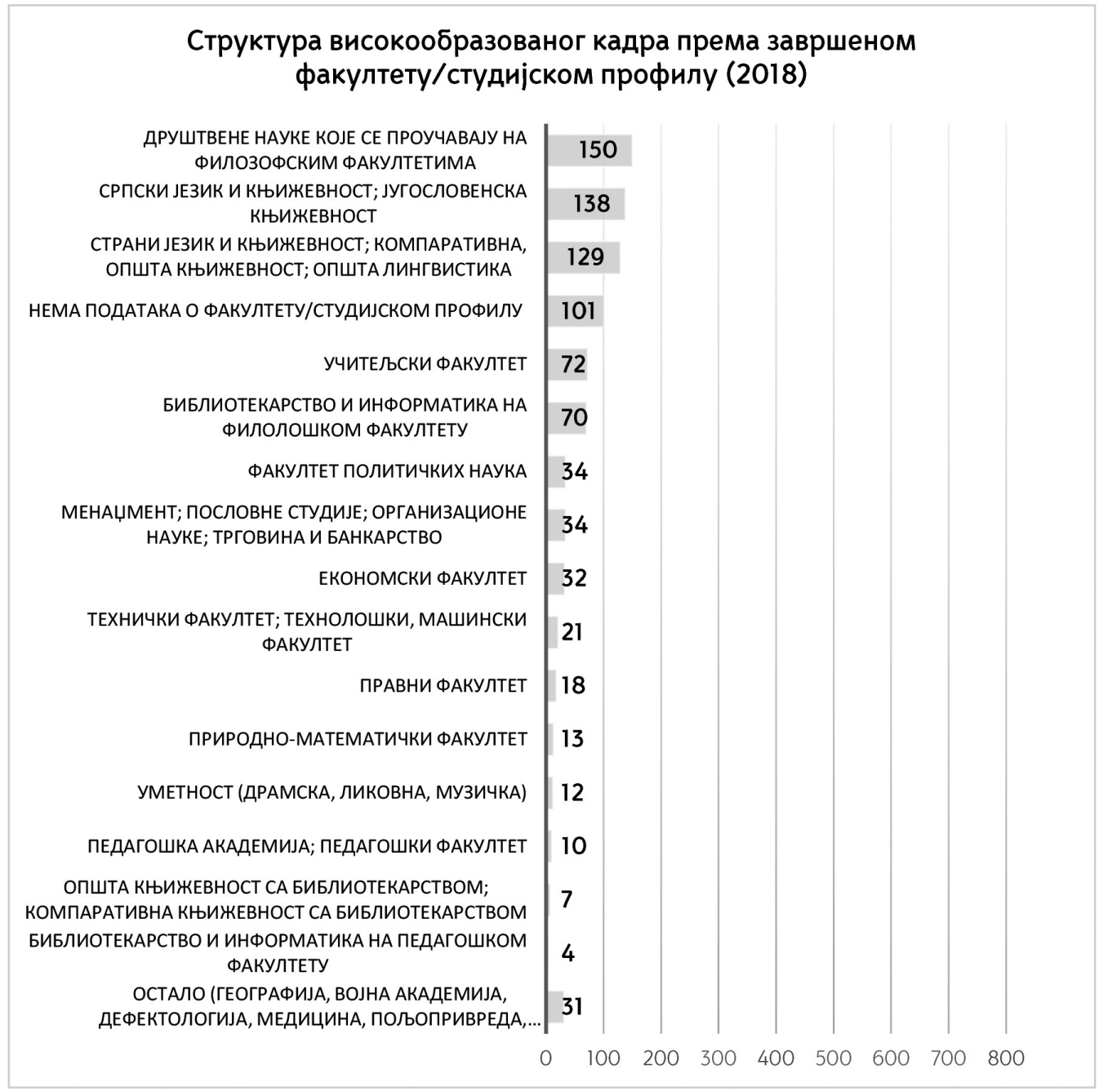

\section{Графички приказ бр. 4}

пута и то обухвата „прање врата, прозора, радијатора, сијалица и зидова“, али зато не могу да препоруче колико би библиотекара са дипломом стеченом на студијама библиотечко-информационих наука, или колико професора језика и књижевности требало да има у колективу, у односу на одређен обим фонда или број становника насељеног места. ${ }^{18}$ Систематизација радних места у српским библиотекама такође ретко прецизира потребан студијски програм за позицију библиотекара. ${ }^{19}$ Понавља се само оно што пише у Закону.

Представљене структуре показале су који стручњаци, према неписаном правилу, имају већу или мању предност при запошљавању у јавним библиотекама. Заступљеност различитих професија унутар једне - библиотекарске - требало би да библиотеку представи као демократичну организацију која производи креативне идеје и може да одговори најразличитијим културним и образовним потребама грађана који у њу долазе. Овакве позитивне особине требало

\footnotetext{
18 "Правилник о националним стандардима за обављање библиотечко-информационе делатности“, Службени ілласник РС број 39 (2013), тачка 2.5 Одржавање хигијене.

19 Гордана Стокић Симончић и Жељко Вучковић., „Професионално образовање и стручно усавршавање школских библиотекара

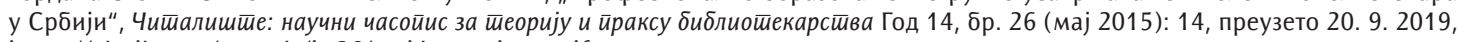
https://citaliste.rs/casopis/br26/stokic_gordana.pdf.
} 
би, затим, да доведу и велики број корисника у библиотеке. Ипак, тренутна ситуација показује да је број корисника испод стандарда који прописује национални правилник. ${ }^{20}$ Овакво стање не мора нужно бити изазвано структуром запослених, али свакако указује да је потребно преиспитати тренутна правила и прописе за рад, између осталог и оне који се односе на запослене у библиотекама.

Како обезбедити погодан кадар за библиотеке, питање је које се у Србији поставља готово стотину година, дакле и пре постојања било какве школе за библиотекаре. Деценијама уназад, па и у данашње време, не влада мишљење да библиотекар може да буде само онај ко има завршене основне или мастер студије из области библиотекарства и информатике, напротив, одређени број запослених показује отворену сумњу у знање и стручност дипломираних библиотекара. Оно што се сигурно зна јесте да је библиотекама потребан кадар који је спреман да ради у променљивом окружењу, технолошки добро обучен, са изразитом вештином комуникације, критички настројен према новим информацијама. ${ }^{21}$ Тиме се руководе катедре за библиотекарство и информатику приликом планирања студијских програма како у Србији, тако и у свету. Библиотекари који су школовани за овај позив јасно знају која је мисија библиотека, шта су њихови производи, какве све програме библиотеке могу да организују, како се одређују циљне групе, како се долази до квалитета, а како квалитетом до корисника.

Интересантно је изнети и податак да је положени стручни испит, од укупног броја запослених у 2018. години, имало њих 1580, док је готово 300 запослених радило без положеног стручног испита. ${ }^{22}$ С обзиром на то да већина њих нема ни диплому из области библиотекарства, око $15 \%$ запослених се обучавало за посао у библиотеци уз помоћ старијих и искуснијих колега. Стручњаци из других сфера свакако имају своје квалитете, али им је ипак потребно одређено време да овладају стручним библиотечким пословима и да се упознају са смислом библиотечког рада, а неки не могу, или не желе, да се сроде са библиотекарском професијом, јер су у њу дошли силом прилика. Хетерогеност која постоји тешко може да подстакне заступање истих вредности и кретање ка истим циљевима те отежава изградњу професионалног идентитета.

За почетак би било добро проучити прописе земаља које по овом питању боље стоје, па на основу тога експлицитније прописати који би образовни профили, и у коликој мери, требало да буду заступљени у јавним библиотекама.

\section{Закључак}

Кроз ово истраживање изнети су подаци који јасно указују на тренутно стање стручног кадра у јавним библиотекама. Позитивно у њему је то што највећи број запослених на стручним пословима има факултетску диплому. Хетерогеност у погледу заступљености струка може да допринесе богатијој понуди библиотека али, у исто време, може бити узрок опречних ставова и стремљења која некад успоравају остваривање мисије библиотека. Важно је запошљавање и стручног кадра из области библиотекарства, јер ако се у обзир узме претпоставка да људи студирају оно што воле, онда ће при добијању посла у струци имати велику мотивацију да свој ентузијазам и труд покажу на делу. Са друге стране, онима који раде у библиотекама јер нису успели да пронађу посао који би испунио њихова преофесионална и лична очекивања,

\footnotetext{
20 Број регистрованих корисника јавних библиотека, у 2017. години, био је 530.273, што је 7,53\% укупног броја становника (7.040.272 на основу процене Републичког завода за статистику). Национални стандард каже да би број уписаних корисника требало да обухвати најмање $12 \%$ укупног броја становника града/општине. - Републички завод за статистику и Завод за проучавање културног развитка, Кулйура 2017 (Београд: Републички завод за статистику, 2018), преузето 25. 8. 2019, http:// publikacije.stat.gov.rs/G2018/Pdf/G20186003.pdf.

21 Henrietta Verma, "Teaching to the team", Library Journal Vol. 143 Issue 4 (March 1, 2018): 24, 25.

22 Према 47 члану Закона о библиотечко-информационој делатности, стручно оспособљавање за практични рад у библиотеци за запослене на стручним пословима с високим и вишим образовањем траје годину дана, а са средњим образовањем - девет месеци. Запосленом који у року од три године рада у библиотеци не положи стручни испит престаје радни однос даном истека тог рока.
} 
нажалост, у великој мери може недостајати посвећености и интересовања.

Закључује се да би требало наћи равнотежу кроз заједнички рад старијих и млађих колега, оних који су завршили студије на Катедри за библиотекарство и информатику и оних са других факултета, ради заједничке мотивације и постизања свеопштег циља - подизања свести о важности коришћења услуга библиотека.

\section{Литература и извори:}

1. „Pravilnik o nacionalnim standardima za obavljanje bibliotečko-informacione delatnosti”. Službeni glasnik RS broj 39 (2013).

2. Republički zavod za statistiku i Zavod za proučavanje kulturnog razvitka. Kultura 2017. Beograd: Republički zavod za statistiku, 2018. Preuzeto 25. 8. 2019. http://publikacije.stat.gov.rs/G2018/Pdf/ G20186003.pdf.

3. Stokić, Gordana. „Zaposleni u bibliotekama o sebi ili ima li mesta osećanju inferiornosti?“. Zajednica biblioteka: informativni organ Zajednica matičnih biblioteka Srbije 20, br. 1/2 (1997): 42-52.

4. Stokić Simončić, Gordana i Željko Vučković. „Profesionalno obrazovanje i stručno usavršavanje školskih bibliotekara u Srbiji“. Čitalište: naučni časopis za teoriju i praksu bibliotekarstva Godina 14, broj 26 (maj 2015): 12-18. Preuzeto 20. 9. 2019. https://citaliste.rs/casopis/br26/stokic_gordana.pdf.

5. Verma, Henrietta. "Teaching to the team". Library Journal Vol. 143 Issue 4 (March 1, 2018): 24-28.

6. "Zakon o bibliotečko-informacionoj delatnosti”. Službeni glasnik Republike Srbije br. 52 (2011). Preuzeto 10. 8. 2019. http://www.kultura.gov.rs/docs/dokumenti/propisi-iz-oblasti-kulture/-zakon-o-bibliotecko-informacionoj-delatnosti.doc.

\section{Educational Structure of Employees in Serbian Public Libraries}

\section{Summary}

The paper presents the structure of employees in public libraries according to the level and field of education. Data relating to 2018 and 2013 have been highlighted in order to determine the effect of the ban on public secto employment that was enacted at the end of 2013. It is evident that the number of employees with a high school degree and a college degree has decreased while the number of university graduates has increased.

As it is not specified, at any level, who can do the job of a graduate librarian, the aim is to determine which professions are represented among the highly educated employees in public libraries. Employees with a bachelor's or master's degree in librarianship are grouped into a special category, in order to find out what percentage of the staff with higher education they make.

The fact that the number of library users in Serbia is below all standards indicates that something needs to be changed. First of all, it would be good to examine the current situation in Serbia and study the regulations in the countries that are more advanced in this matter, and then to specify more explicitly what educational profiles should be represented in public libraries here.

Balance should be found through the joint work of older and younger experts, those who have completed their studies at the Department of Library and Information Science, and those from other faculties, in order to find motivation and achieve a common goal - raising awareness of the importance of using libraries.

Keywords: public libraries, staff structure, librarians, education, Department of Library and Information Science, the Republic of Serbia 
